\title{
APPLICATION OF THE PROPERTIES OF NAQLI AND AQLI IN POSITIVE LAW WITH RESPECT TO ISLAMIC CONTRACT LAW
}

\author{
Irena Dwi Fetraningtyas \\ Master of Law Science, Faculty of Law, Diponegoro University \\ irenaswi33@gmail.com \\ Yunanto \\ Master of Law Science, Faculty of Law, Diponegoro University \\ yun_yunanto@yahoo.com
}

\begin{abstract}
Abstrak: Konsep bertransaksi dalam Ekonomi Islam disebut sebagai akad. Akad adalah perikatan yang ditetapkan dengan ijab dan qabul berdasarkan ketentuan syara' yang berdampak pada objeknya. Semua perikatan atau transaksi yang dilakukan oleh para pihak, dua pihak atau lebih tidak boleh menyimpang dan sejalan dengan kehendak sya'riat. Tidak boleh ada kesepakatan untuk menipu orang lain, tidak boleh bertransaksi yang mengandung unsur maisir, gharar, riba dan bathil. Serta tidak boleh bertransaksi dengan barang atau harta yang diharamkan, maal ghairu mutaqawwim. Dalam bertransaksi secara ekonomi Islam, terdapat dalil Naqli dan Aqli. Dalil naqli dapat diartikan sebagai tanda bukti atau petunjuk dari teks ayat Al-Quran, dalil tersebut kebenarannya merupakan mutlak atau hakiki. Penelitian ini menggunakan metode penelitian yuridis normatif dengan data sekunder. Hasil penelitian menyimpulkan dalil Aqli adalah dalil yang dapat dinalar oleh akal fikiran. Dua dalil tersebut lahirlah dasar atau prinsip ekonomi Islam yang tidak boleh menyimpang dari Al-Quran dan Al-Hadits. Hal tersebutlah yang akan melahirkan asas-asas kebolehan dalam ekonomi Islam. Penelitian ini akan membahas bagaimana fungsi dalil Naqli dan Aqli dalam Hukum Ekonomi Islam, dan bagaimana penerapan Dalil Naqli dan Aqli dalam Hukum Positif Berkenaan Dengan Hukum Akad (Perjanjian) Islam.
\end{abstract}

Kata Kunci: Akad, Ekonomi Islam, Dalil Naqli dan Aqli.

Abstract: The concept of transacting in Islamic Economics is referred to as akad.
Akad is an alliance established by ijab and qabul based on the provisions of syara
'that affect its object. All alliances or transactions entered into by the parties, two
or more parties must not deviate and in accordance with the requirements of the
Shari'ah. There can be no agreement to deceive others, there can be no transactions
that contain elements of maisir, gharar, riba and bathil. As well as not being able
to transact with goods or property that are forbidden, maal ghairu mutaquwwim.
In dealing in Islamic economics, there are Naqli and Aqli propositions. Dalil naqli 
SYARIAH: Jurnal Hukum dan Pemikiran Volume 21, No.1, June 2021 | 60

can be interpreted as a sign of evidence or clue from the text of the verses of the Qur'an, the evidence is the truth is absolute or essential. This study uses normative juridical research methods with secondary data. The results of the research conclude that Aqli's proposition is a proposition that can be reasoned by the mind. These two propositions are the birth of the principles or principles of Islamic economics that must not deviate from the Qur'an and Hadith. That is what will give birth to the foundations of competence in Islamic economics. This study will discuss how the function of Naqli and Aqli propositions in Islamic Economic Law, and how the application of Naqli and Aqli propositions in Positive Law with respect to Islamic Covenant Law.

Key Words: Contract, Economic Islam, Propositions of Naqli and Aqli

\section{INTRODUCTION}

Human life cannot be separated from one another, because basically, humans are social creatures. Humans as social beings; in fact, humans are born as individuals who have needs that must be fulfilled; to meet these needs, humans need to create social relationships between one human and another human. ${ }^{1}$ Human life also includes transactions between humans one another. ${ }^{2}$ One of them is through an economic perspective, especially the Islamic economy, because Indonesia is a country with the largest Muslim population globally. ${ }^{3}$

Islamic teachings in economics such as the prohibition of Maisir, Gharar, and usury, hoarding or playing with offers (ikthiar), playing with requests (najasy),

\footnotetext{
1 Meilanny Budiarti S, 'Mengurai Konsep Dasar Manusia Sebagai Individu Melalui Relasi Sosial Yang Dibangunnya', in Prosiding Penelitian Dan Pengabdian Kepada Masyarakat (Bandung: Universitas Padjajaran, 2017), pp. 104.

2 Folke Schmidt, 'The International Contract Law in The Context of Some of Its Sources', The American Journal of Comparative Law, 14.1 (2011), 31.
}

cheating (tadlis), taghrir, and selling goods that do not belong to him (bai 'al ma'dum), fraudulent weighing, exploitation of natural resources recklessly, waste, greed and so on have been widely practiced in everyday economic life ${ }^{4}$ And is considered as something familiar and accepted in the practice of society, nation, and the state of Indonesia.

In carrying out their lives, humans are given the mandate by Allah SWT to carry out their duties on this earth as best as possible and cannot be separated from the values and norms shared by Allah SWT, which are known as sharia. Likewise, with economic life, because the economy is one of the aspects of human life, both regular and massive, therefore, so that it is not far from Him, Islam also regulates several

\footnotetext{
3 Ach. Yasin Clarashinta Canggih, Khusnul Fikriyah, 'Potensi Dan Realisasi Dana Zakat Indonesia', Al-Uqud: Journal of Islamic Economics, 1.1 (2017), 14-26.

4 Itang Itang, 'Dasar Hukum Ekonomi Islam', ISLAMICONOMIC: Jurnal Ekonomi Islam, 5.2 (2014), 1-13.
} 
things in transactions, that is what is then called Islamic Economics. ${ }^{5}$

Islam is described as one of the most recently derived religions. Therefore Islam can be said to be a perfected religion listed in the QS. Al-Ma'idah (5) verse (3). Thus, the concept of Islamic economics is understood as a system that can be used as a guide for humans in carrying out economic activities. A system which in general has been regulated in the Quran and Sunnah. The basis of Islamic Economics consists of Al-Quran, AlHadits, and Itjihad.

Based on the narrative of Yusuf Qardhawi, the meaning of Islamic economics is "an economy based on Godhood. The essence of this economic system starts from Allah; its ultimate goal is Allah and uses the means that cannot be separated from the Shari'ah; at Allah. Islamic economics is a prohibition against wrongdoing and wrongdoing each other. The Islamic economic system is based on a philosophy related to al-tauhiq, al rububiyah, and al-istikhlaf. ${ }^{6}$ There are

5 Mustafa Edwin, Pengenalan Eksklusif Ekonomi Islam (Jakarta: kencana Prenada media Group, 2010), pp. 34.

6 Asmuni Mth, 'Konsep Pembangunan Ekonomi Islam', Al-Muwarid, 10.1 (2003), 130. several principles of the contract (agreement) in Islamic Economic Law:

1. Al- ushul (general principles)

2. Al- furu' (concrete legal rules)

Because the principles in the contract are by the Islamic Economic Law, Syamsul Anwar ${ }^{7}$ argued that the norms of Islamic contract law can be categorized into several levels, among others;

1. Basic values or philosophical norms (Al-qiyam al- assasiyyah)

2. General principles (Al- ushul alkulliyyah)

3. Concrete legal regulations (Alahkam al-far'iyyah)

The level or norm which will prove the crystallization of the arguments of naqli and aqli in positive law or national law that applies today. Then, in simple terms, it can be concluded that the naqli view is the argument that comes from the Al-Quran and Al-Hadith; this argument is to bring people closer to goodness and away from evil. Meanwhile, the idea of aqli, comes from human reason, which must be based on Shari'a values and stay away from tyranny. However, in priority, naqli

7 Syamsul Anwar, Hukum Perjanjian Syariah, Studi Tentang Teori Akad Dalam Fiqh Muamalat (Jakarta: Raja Grafindo Persada, 2010) pp. 91. 
arguments must always take precedence before aqli fight. One of the cases that could be used as a reason for conducting this research was the bad credit case between a private Islamic bank in Bandung and Sugihato, in which the judge also considered the naqli argument before the aqli argument. ${ }^{8}$ Departing from these problems then the research problems that will be discussed in this research are: What are the opinions of naqli and aqli in Islamic economic law? How is the application of these naqli and aqli arguments in today's positive law?

\section{METHOD}

The approach method used in this research is the juridical-normative approach, namely research that is specialized in researching library materials or secondary data. ${ }^{9}$ The juridical approach refers to the prevailing laws and regulations. Simultaneously, the normative system that is meant is an approach that is carried out by examining library materials

8 Eko Sutriyanto, 'Berkaca Pada Kasus Sugiharto, Sengketa Perbankan Syariah Diadili Di Pengadilan Agama', Tribunnews, 2020 $<$ https://www.tribunnews.com/regional/2018/11/08/berkaca-pada-kasussugiharto-sengketa-perbankan-syariah-diadili-di-pengadilan-agama $>$.

9 Zainudin Ali, Metode Penelitian Hukum (Jakarta: Sinar Grafika, 2009)pp.35. or secondary data on legal principles and case studies or applications to be referred to as literature law research. ${ }^{10}$ The analytical approach method used is descriptive-analytical, which is a way of analysis by describing the object of research, ${ }^{11}$ then a conclusion is drawn to answer the research problem.

\section{RESULTS AND DISCUSSION}

\section{The arguments of Naqli and Aqli in Islamic Economic Law}

Naqli arguments are arguments derived from teachings derived directly from the teachings of Allah SWT so that the valid sources of Naqli's opinion are AlQuran, As-Sunnah, and Al-Hadith. AlQuran is the word of Allah SWT, which was conveyed by the Prophet Muhammad, peacefully, through the angel Jibril. AlQuran is the basis of the eternal and original Islamic economic law. It is the source and the first reference for the Islamic sya'riat because, in it, there are

\footnotetext{
10 Sabian Utsman, Metodologi Penelitian Hukum Progresif (Yogyakarta: Pustaka Pelajar, 2014) pp. 33.

11 Kornelius Benuf and Muhamad Azhar, 'Metodologi Penelitian Hukum Sebagai Instrumen Mengurai Permasalahan Hukum Kontemporer', Gema Keadilan, 7.1 (2020), 25.
} 
global rules and their details. ${ }^{12}$ This is stated in the QS. An-Nisa (4) verse (80).

QS. An-Nisa states that the Qur'an explains the syara laws' as a whole because the explanations as-Sunnah also come from the Al-Qur'an. The A-Qur'an as the primary source for all Islamic law, explains the basics of the law, such as ordering humans to fulfill promises (commitments) and affirming the halal transaction of buying and selling and the prohibition of usury transactions. ${ }^{13}$

Furthermore, about naqli argument, the source that must be used as a guide is Sunnah. As-Sunnah is often referred to as Al-Hadith, which means everything that the Prophet Muhammad (PBUH) relies on in the form of words, deeds, and takrir. Even if there are differences, it is hoped that these differences are not significant, while AlHadith, is not only based on anything that is based on the Prophet Muhammad, but also on the companions of the Prophet. ${ }^{14}$ As-Sunnah needs to understand its position towards the Al-Quran; this can be formulated in 3 things ${ }^{15}$ :

\footnotetext{
12 Muhammad Abu Zahrah, Ushul Fiqh (Jakarta: Pustaka Firdaus, 1994) pp.22.

13 Ahmad Hanafi, Pengantar Dan Sejarah Hukum Islam (Jakarta: Bulan Bintang, 1986), pp.57.
}

1. Sunnah functions to explain verses that are still mubham, detailing the mujmal verses.

2. Sunnah adds to the obligations of syara 'whose main provisions have been applied to the texts of the AlQuran. Sunnah is to complete the basic provisions of the Al-Quran.

3. Sunnah bring laws that have no provisions in the text $\mathrm{Al}$-Quran.

As in the case of mu'amalat, Al-Quran commands to fulfill the contract (commitment). In this case, Al-Quran only specifies which contract (agreement) is lawful and which deal is haram; the rest of the Sunnah functions to explain. So that it can be understood that the Quran and sunnah have a relationship between one another, between the Quran and the sunnah have a relationship, namely, if the Al-Quran functions to sort out what is halal and what is haram and then it is the sunnah that will explain why it is haram and why it is halal.

The source for the last naqli argument is Ijtihad, Ijtihad is all abilities in all actions to approach sharia law by the naqli

\footnotetext{
14 Hasbi as-Shiddieqy, Sejarah Dan Pengantar Ilmu Hadits (Jakarta: Bulan Bintang, 1991)pp. 65.

15 Qardhawi Yusuf, Ijtihad Dalam Syari'at Islam (Jakarta: Bulan Bintang, 1987), pp. 53.
} 
opinion. ${ }^{16}$ Ijtihad is explained in QS. AsShura '(42) verse (38). The scope of ijtihad are issues that have not been regulated by the Al-Quran and Sunnah. If a provision on a matter, including the contract (agreement), has been held in the AlQuran and As-Sunnah, then a person does not need to perform ijtihad but carry out procedures applicable provisions. ${ }^{17}$ In transacting by contract in Islamic law, three main things are regulated in ijtihad, namely;

1. How to obtain property rights over an object;

2. Confirmation regarding property rights;

3. Obligation to spend property.

The way to get a property right through a contract must be in a lawful manner. By the word of Allah SWT in QS. Al-Baqarah

(2) Verse (188), as follows;

"And do not some of you eat the property of some of you in an immoral way and (do not) bring the affairs of that property to the judge, so that you may eat part of the property of the other person by sinning, even though you know it." (Q.S Al-Baqarah, verse 188)

16 Qardhawi Yusuf, pp. 19.
The method of obtaining rights to a contract is also prohibited using usury. Usury means getting the benefits obtained through the efforts of others without paying for these efforts; in this case, it can be categorized as the default of a contract or fraud. Usury is a big disaster, calamity, and devastating disease, according to the word of Allah SWT in QS. Adz-Zariyat (51) paragraph (19). Usury is an activity to take the added value that is burdensome from an economic contract, such as buying and selling and debt and credit. Usury also refers to the excess of the principal amount lent by lenders to borrowers. In the sense of language, usury has an additional meaning, or in Arabic, it is called azziyadah. What is meant by addition to the meaning of usury is an illicit business which harms one of the parties in the transaction process. Reporting from NU Online, according to Tafsir at-Tabari, the meaning of usury refers to the tradition of transactions carried out by the ignorant community. As for usury in buying and selling transactions, it can occur when there is a rescheduling of purchase debt

\footnotetext{
17 Wahab Afif, Tarikh Tasyri Islam (Serang: CV. Saudara, 2011),
} pp.12. 
accompanied by an additional price that exceeds the agreed price. According to Abdurrahman Al-Jaziri in the book AlFiqh ala al-Madzahib al-Arba'ah, usury is the increase in one of two similar exchanges without any compensation for this addition so that the scholars all agree that usury is an unlawful activity.

The naqli argument was born from standard and valid guidelines directly revealed by Allah SW'T on Muslims; again, the essence of the naqli idea is to keep people away from the nature of wrongdoing and wrongdoing. ${ }^{18}$ However, then, humans are obliged to interpret these values in creating standard rules or laws for each other; this interpretation is then called the argument of aqli or reason for reason. The idea of aqli must be relevant and close together and based on the naqli opinion which is Sharia. ${ }^{19}$ The value of the argument of aqli must not contradict the idea of naqli; if it is contradictory, it can be said that this

18 Hanifullah, 'Membangun Sistem Ekonomi Umat Berbasis Syariah', Epistemé: Jurnal Pengembangan Ilmu Keislaman, 7.2 (2012), 267-292.

19 Hugo Schutz, 'Islamic Culture of Law', The Journal of Islamic Law and Culture, 5.1 (2011), 34-54.

20 Fathul Aziz, 'Fiqh Ibadah Dan Figh Muamalah', Jurnal IAIN Purwokerto, 7.2 (2019), 29. argument is not valid according to the Islamic contract Law. ${ }^{20}$

\section{The application of Naqli and Aqli propositions in positive law concerning Islamic contract law}

As previously understood, the legal system is a fundamental standard rule arranged in an integrated manner based on certain principles. As a system, law consists of sub-systems that must be related, balanced, harmonious, harmonious, and not overlapping. In this case, the focus is on Civil Law or National Law, ${ }^{21}$ It should be in line with the arguments or principles of Islamic contract law.

The Islamic legal system is an integrated whole legal regulation. ${ }^{22}$ Islamic law or Islamic law is a system of rules based on the revelations of Allah SWT and the Sunnah of the Prophet regarding the behaviour of mukalaf (people who can be burdened with obligations) that are recognized and believed, which are

\footnotetext{
21 Darius Mariam Badrulzaman, Jaminan-Jaminan Untuk Pemberian Kredit Menurut Hukum Indonesia (Bandung: Citra Aditya Bakti, 1991), 15.

22 Neni Sri Imaniyati, Asas Dan Jenis Akad Dalam Hukum Ekonomi Syariah: Implementasinya Pada Usaha Bank Syariah (Bandung: Universitas Islam Bandung, 2011), 55.
} 
binding for all adherents. And this refers to what has been done by the Apostle to carry it out totally. Islamic Sharia, according to the term means the laws ordered by Allah SWT for His people brought by a Prophet, both those related to belief (aqidah) and those related to Aaliyah. Islamic Sharia, according to language, means the path through which humanity leads to Allah Ta'ala. And it turns out that Islam is not only a religion that teaches about how to worship only God. The existence of a rule or system of provisions of Allah SWT to regulate human relations with Allah Ta'ala and human relations with each other. These rules are rooted in all Islamic teachings, especially the Al-Quran and Hadith. Based on certain principles. By what was explained in the previous section, about the level of norms described by Syamsul Anwar, then in the intermediate layers;

Basic values or philosophical norms

General principles

Concrete legal regulations

So it can be interpreted that a concrete legal rule is a concretization or

23 Ahmad Mahtum, 'Intervensi Negara Dalam Ekonomi Islam', Pamakasan, 1.1 (2018), 44

24 Kornelius Benuf Ery Agus Priyono, Achmad Busro, Islamiyati, Dharu Triasih, Novita Dewi Masyithoh, 'The Application of the Principle of crystallization of general principles and is manifested in taklifi legal provisions such as halal, haram, obligatory, sunnah, and permissible. ${ }^{23}$ Based on this, the Civil Code regulates the validity of an contract about the obligations that must be fulfilled in an individual engagement with another individual. This is held in Ps. 1320 Civil Code four things must be fulfilled to make a contract valid, among others; There is an agreement for those who tie themselves

1. The ability of the parties to make an engagement

2. A certain thing

3. A cause (causa) or a legal cause.

An agreement can be said to be a legal flaw when the deal is deemed nonexistent, about the validity of the agreement, if there is no agreement, the agreement does not fulfill the objective conditions of a contract, the legal consequence is that the agreement is null and void, and must be declared. back to its original state ${ }^{24}$, the agreement is invalid if the following things happen;

The existence of coercion (dwaang), namely the presence of unfair actions or

Justice in a Partnership Agreement in the Framework of Implementing the National Fish Logistics System in Indonesia', AACL Bioflux, 13.3 (2020), 1963. 
threats that hinder the freedom of will of the parties involved in the contract. This coercion is intended to make one of the parties give up their rights free of charge.

Fraud (bedrog) listed in Ps. 1328 Civil Code that copy can be used as a reason for the cancellation of an agreement.

The existence of good faith (good faith) from one party and the other party in being attached to a contract is the basis for running the engagement legally and adequately. However, if there are reasons for a person, even his intention, to deny or default on an agreement, then this can cancel the contract (voidable).

\section{CONCLUSION}

Based on the above discussion, it can be concluded that: The naqli and aqli arguments become standard guidelines for a Muslim in making contracts with one another; the naqli idea is based on the necessary provisions of the Al-Quran and Sunnah Meanwhile, ijtihad is implemented based on conditions that are not regulated in 2 (two) requirements of the Al-Quran and Sunnah. The argument of aqli or reason is the crystallization of the naqli opinion in human economic life. It is obliged to be guided by or adjacent and based on the sharia taught by Allah SWT.

The principles of the contract in Islamic Economic law are the principle of ibahah (mabda'al-ibhahah), the principle of freedom of contract (mabda 'huriyyah at ta'aqud) and the principle of consesualism (mabda' ar-radha'iyyah), the principle that the promise binds the principle of balance. And the focus of benefit and the direction of thrust, and the last is the principle of justice. The crystallization of concrete legal guidelines for Islamic law is contained in Ps. 1320 Civil Code regarding the validity of an agreement. The cancellation of a contract based on fraud or coercion is regulated in Art. 1328 Civil Code. An agreement must be based on something lawful and not based on pressure. This is a form of concretization of national law that is adjacent to Islamic contract law.

\section{REFERENCES}

Afif, Wahab, Tarikh Tasyri Islam (Serang: CV. Saudara, 2011)

Ahmad Hanafi, Pengantar Dan Sejarah Hukum Islam Jakarta: Bulan Bintang, 1986) 
Asmuni Mth, Konsep Pembangunan Ekonomi Islam', Al-Muwarid, 10.1 (2003), $128-51$

Benuf, Kornelius, and Muhamad Azhar, Metodologi Penelitian Hukum Sebagai Instrumen Mengurai Permasalaban Hukum Kontemporer', Gema Keadilan, 7.1 (2020), 20-33

Clarashinta Canggih, Khusnul Fikriyah, Ach. Yasin, Potensi Dan Realisasi Dana Zakat Indonesia', Al-Uqud: Journal of Islamic Economics, 1.1 (2017), 14-26

Darius Mariam Badrulzaman, JaminanJaminan Untuk Pemberian Kredit Menurut Hukum Indonesia (Bandung: Citra Aditya Bakti, 1991)

Edwin, Mustafa, Pengenalan Eksklusif Ekonomi Islam Jakarta: kencana Prenada media Group, 2010)

Ery Agus Priyono, Achmad Busro, Islamiyati, Dharu Triasih, Novita Dewi Masyithoh, Kornelius Benuf, The Application of the Principle of Justice in a Partnership Agreement in the Framework of Implementing the National Fish Logistics System in Indonesia', AACL Bioflux, 13.3 (2020), 1963-69

Fathul Aziz, Figh Ibadah Dan Fiqh Muamalah', Jurnal LAIN Purvokerto, 7.2 (2019), 24-45

Hanifullah, 'Membangun Sistem Ekonomi Umat Berbasis Syariah', Epistemé: Jurnal Pengembangan Ilmu Keislaman, 7.2 (2012), 267-92
Hasbi as-Shiddieqy, Sejarah Dan Pengantar Ilmu Hadits (Jakarta: Bulan Bintang, 1991)

Hugo Schutz, 'Islamic Culture of Law', The Journal of Islamic Law and Culture, 5.1 (2011), 34-54

Imaniyati, Neni Sri, Asas Dan Jenis Akad Dalam Hukum Ekonomi Syariah: Implementasinya Pada Usaha Bank Syariah (Bandung: Universitas Islam Bandung, 2011)

Itang, Itang, Dasar Hukum Ekonomi Islam', ISLAMICONOMIC: Jurnal Ekonomi Islam, 5.2 (2014), 1-13

Mahtum, Ahmad, Intervensi Negara Dalam Ekonomi Islam', Pamakasan, 1.1 (2018), 37-47

Meilanny Budiarti S, Mengurai Konsep Dasar Manusia Sebagai Individu Melalui Relasi Sosial Yang Dibangunnya, in Prosiding Penelitian Dan Pengabdian Kepada Masyarakat Bandung: Universitas Padjajaran, 2017), pp. 104-9

Qardhawi Yusuf, Ijtihad Dalam Syariat Islam (Jakarta: Bulan Bintang, 1987)

Sabian Utsman, Metodologi Penelitian Hukum Progresif (Yogyakarta: Pustaka Pelajar, 2014)

Schmidt, Folke, The International Contract Law in The Context of Some of Its Sources', The American Journal of Comparative Law, 14.1 (2011), 1-37

Sutriyanto, Eko, Berkaca Pada Kasus Sugiharto, Sengketa Perbankan Syariah Diadili Di Pengadilan 
69 |Irena, Yunanto, Application of the Properties of Naqli and Aqli in..., pp. 59-67

Agama', Tribunnews, 2020 $<$ https://www.tribunnews.com/r egional/2018/11/08/berkacapada-kasus-sugiharto-sengketaperbankan-syariah-diadili-dipengadilan-agama>

Syamsul Anwar, Hukum Perjanjian Syariah, Studi Tentang Teori Akad Dalam
Figh Muamalat (Jakarta: Raja Grafindo Persada, 2010)

Zahrah, Muhammad Abu, Ushul Fiqh (Jakarta: Pustaka Firdaus, 1994)

Zainudin Ali, Metode Penelitian Hukum (Jakarta: Sinar Grafika, 2009) 